\title{
THE HISTORY OF RAGWEED IN THE WORLD
}

\author{
MAKRA, L. ${ }^{1} *$ - MATYASOVSZKY, I. ${ }^{2}-$ HUFNAGEL, L. ${ }^{3}-$ TUSNÁDY, G. ${ }^{4}$ \\ ${ }^{I}$ Department of Climatology and Landscape Ecology, University of Szeged, \\ HU-6701 Szeged, P.O.B. 653, Hungary; \\ (phone: +37-70-294-1310; fax: +36-62-544-624) \\ ${ }^{2}$ Department of Meteorology, Eötvös Loránd University, \\ HU-1117 Budapest, Pázmány Péter st. 1/A, Hungary; \\ (phone: +36-30-480-1832) \\ ${ }^{3}$ Adaptation to Climate Change Research Group, \\ Corvinus University of Budapest, Hungary; \\ (phone: +36-1-294-9875) \\ ${ }^{4}$ Mathematical Institute of the Hungarian Academy of Sciences, \\ HU-1364 Budapest, P.O.B. 127, Hungary; \\ (phone: +36-1-483-8324) \\ *Corresponding author \\ e-mail: makra@geo.u-szeged.hu \\ (Received $4^{\text {th }}$ Sept 2014; accepted $1^{\text {st }}$ Dec 2014)
}

\begin{abstract}
The aim of the study is to provide a survey on the history of ragweed worldwide. Its climate dependence, impacts in agriculture, health effects and social costs are also presented. In Europe common ragweed (Ambrosia artemisiifolia) is predominant of all Ambrosia species that is supported by population genetic data. The most important habitat areas of ragweed and the highest pollen concentrations occur, in decreasing order of the pollen levels (1) in the south-western part of the European Russia, (2) in the southern and eastern parts of Ukraine, (3) in the Pannonian Plain in Central Europe, (4) in the RhôneAlpes region in France, furthermore (5) in the Po River valley in Italy. Besides Europe, ragweed occurs in China, India, Japan and in other Asian countries, furthermore in Australia and the Unites States of America. However, beyond the USA few information are available. Warming trends due to the climate change favours the expansion of ragweed, producing higher pollen levels worldwide. In association with the warming, increasing ambient $\mathrm{CO}_{2}$ levels generate greater biomass and increased pollen production. Hence, ragweed pollen production can be expected to increase significantly under predicted future climate conditions, bringing severe impacts to areas that have yet been suffering slightly.
\end{abstract}

Keywords: origin of ragweed, social costs of ragweed, distribution of ragweed, climate change, respiratory allergy

\section{Introduction}

\section{Origin of ragweed}

Common ragweed (Ambrosia artemisiifolia) (Asteraceae family) is an annual species, native to North America, which has been introduced and subsequently naturalized in many countries including a large part of Europe (Jäger, 1998; Juhász, 1998; Rybníček and Jäger, 2001; Bullock et al., 2010), Asia and Australia (Lawalrée, 1953; Priszter, 1960) following its introduction to many places in the world. The name Ambrosia is the same as that of the delicious food eaten by the mythical Greek gods that conferred them immortality (Makra et al., 2004). The term might refer to the tenacity of the plants, which makes it hard to rid an area of them if they occur as invasive weeds. 
The genus is best known for the severe and widespread allergies caused by its pollen (Béres, 2003).

Ambrosia artemisiifolia belongs to the phylum of angiosperms (Angiospermatophyta), to the class of Dicotyledonouses (Dicotyledonopsida), to the ordo of Composites (Asterales), to the family of Daisies (Asteraceae), to the subfamily of disc-florets (Tubuliflorae) and to the genus of ragweeds (Ambrosia spp.). This genus comprises 42 species. The most species occur in the Unites States, some of them in Central- and South America, while Ambrosia senegalensis Dc. is native in Africa (Béres et al., 2005).

The Sonora desert in Arizona (USA), north and west of the Bay of California, is considered the gene centre of Ambrosia species (Bohár, 1996), where about 10 species occur (Bohár, 1996). Ambrosia artemisiifolia was discovered in the USA before 1838 (Wagner and Beals, 1958), while in Canada in 1860 (Bassett and Crompton, 1975). There are 41 species worldwide. In Europe, introductions of A. artemisiifolia stems from two different regions of their native area. Namely, populations established in Central Europe appear to have originated from eastern North America and Eastern European populations from more western North America. This may result from differential commercial exchanges between these geographic regions (Gaudeul et al., 2011).

Ambrosia pollen has been found in deposits of over sixty thousand years in Canada. Nevertheless, its amount in peat deposits, except for the last 250 years, is small. However, due to deforestation and land use changes associated with the incursion of the western civiliziation, this amount increased over 100-fold. Recently, ragweed has extended areas in North-America unitl the southern part of Canada (Szigetvári and Benkő, 2004).

\section{Climatic and environmental associations}

Ambrosia species are adapted to the arid climates of the desert. Ragweed favours temperate climate and prefers dry, sunny and grassy plains, sandy soils, river banks, roadsides, and ruderal sites (disturbed soils) such as vacant lots and abandoned fields (Ziska et al., 2006; Kazinczi et al., 2008a; 2008b). Fields along roads are especially suitable for facilitating its spreading. In Quebec Province, Canada in strips of land along the roads 4-16 plants occur per square meter (Simard and Benoit, 2010).

Ragweed can take hold up and prosper if the temperature sum exceeds the threshold of $1400^{\circ} \mathrm{C}$, necessary for its floral and seed development (Cunze et al., 2013). Below this threshold, under maritime climate (north-eastern Spain, Netherlands), ragweed populations seem only survive. At the same time, if the temperature sum is too high, for example in the Mediterranean, summers are hot and dry that involves a substantial decline of pollen release. However, the species is widely distributed in countries that are largely unsuitable for ragweed but import lots of seed, such as Netherlands or Belgium. In these countries, the distribution overstates the very low impact of the casual introductions (Bullock et al., 2010).

Contrary to regular mowing, ragweed grows rapidly, producing rather large amounts of biomass and even they can bloom as well (Patracchini et al., 2011). Their shadow tolerance is also very good, they satisfy with less light. They grow better in shadow compared to native plants (Qin et al., 2012). Their water-use efficiency in the growing period, and their nitrogen-use efficiency and the ratio of photosynthesis/respiration in the blooming period are very high (Pajević et al., 2010). Ambrosia, according to a study performed in Hungary (Pinke et al., 2011), like acidic and sandy soil, however it grows 
rarely in soils containing high $\mathrm{Na}, \mathrm{K}$ and $\mathrm{Mn}$ concentrations. In those years, when rainfall amount in April exceeds $39 \mathrm{~mm}$, or mean temperature in May exceeds $15.5^{\circ} \mathrm{C}$, ragweed coverage increases. Namely, these meteorological components may have of predictive value (Pinke et al., 2011).

Based on stuyding 22 American and 12 European populations, plants in Europe grow faster and reproduce better than the American plants. However, during drought, plants die faster in Europe compared to the plants of the American native populations. This can be explained by the fact that due to the fast growing, European plants are less toleratant to drought (Hodgins and Rieseberg, 2011).

The northern and high-elevation range margin of ragweed is regulated by thermal and photoperiod constraints. Beyond their habitat areas, ragweed occurs casually and is unable to set seeds (Dahl et al., 1999; Saar et al., 2000). In the northern range of its habitat area, even though the populations can produce seed, low temperatures or the cold climate promotes extinction. In general, over these areas ragweed grows to adulthood but fails to reproduce properly because it is too cold. At the same time, in the southern edge of its habitat, drought is considered a major factor limiting the invasion. This is the main aspect explaining a lack of ragweed pollen records from Spain and Portugal, where seed import rates should cause many introductions to occur (Bullock et al., 2010).

For the American populations, blooming period of ragweed has been extending. Accordingly, allergic patients are longer exposed to the effect of the highly allergenic ragweed pollen. Longer blooming period is due to the global warming, since in association with the climate change first frost in fall occurs later (Ziska et al., 2011). Due to the climate change, the climate of Europe will be warmer and Ambrosia will spread towards north and north-east. For this reason it may proliferate over the northern part of France, Germany, the Benelux states, Czech Republic, Poland, the Baltic states, Belarus and Russia, as well (Cunze és mtsai., 2013).

Long-range transport of ragweed pollen (traveling more than $100 \mathrm{~km}$ distance between the source area and the arrival point) can deliver pollen over less polluted areas, e.g. from the Pannonian Plain in Central Europe over the Basin of Vienna, northern Slovakia, Poland, Balkans or northern Greece and in the same way, from Ukraine over Poland (Šikoparija et al., 2009; Makra et al., 2010; Kasprzyk et al., 2011; Šikoparija et al., 2013). Ragweed pollen coming from the Pannonian Plain can reach even the area of Niš and Skopje in the Balkans taking over $400 \mathrm{~km}$ (Šikoparija et al., 2009).

\section{Impacts on agricultural activity}

The extensive spread of $A$. artemisiifolia can be associated to the political transitions in 1990s that led to the formation of young democracies in Eastern Europe. During these processes, the structure and the size of the cultivated areas, as well as land use changed. Namely, co-operatives were cut into smaller parcels due to privatization. Thus large, formerly well-kept agricultural fields were abandoned and quickly colonised by A. artemisiifolia (Kiss and Béres, 2006).

Ambrosia is a noxious agricultural weed. It grows frequently on roadsides, railway embankments, waste places and in cultivated lands. It can overgrow alfalfa and purple clover entirely, cause severe damages in potato fields and occurs often in sunflower and corn fields, as well. Substantial crop failure due to ragweed can be explained by its strong allelopathic effect influencing even life processes of algae in the soil. In corn plantations 1 plant $/ \mathrm{m}^{2}$ ragweed occurrence may cause a yield loss of even 0.2-0.3 tonne / hectare (Varga, 2002). According to a test of inhibition of germination, three 
extractions (water, alcohol and acetone) were prepared and it was found that for each treatment $A$. artemisiifolia decreased germination of soy and corn (Béres et al., 2002).

Ambrosia appears in large quantities in stubbles, effectively utilize large amounts of fertilizer, have high productivity, and regenerate well in dry and infertile soils. Their ability to block sunlight causes reduced crop productivity (Xie et al., 2001). Furthermore, it does not have any natural competitors. Ambrosia has less sensitivity to herbicides than other weeds (Voevodin, 1982; Ballard et al., 1995; Patzoldt et al., 2001; Makra et al., 2014).

Ragweed tolerates leaf loss very well against herbivorous. This time, on the expense of the root system, the plant allocates more nutrients into the stem in order to fast replacement of leaves. According to observations plants in the Euroepan populations produce more seeds, substantially raising the tolerance against grazing (Gard et al., 2013). Invasive species, such as ragweed, indicate a very good model for studying ecological and evolutionary processes having a great role in colonization of new areas (Prentis and Pavasovic, 2013).

\section{Health effects}

Climate change in association with an extended urbanization, with high levels of vehicle emissions in urban areas, living in artificial environment with little movement may contribute to increasing frequency of respiratory allergy and asthma (D'Amato, 2011). Pollen is an important trigger of respiratory diseases. Greater concentrations of carbon dioxide and, consequently, higher temperatures may increase pollen quantity and induce longer pollen seasons (Ziska et al., 2003; Clot, 2008). Pollen allergenicity can also increase as a result of these changes in climate. Furthermore, there is evidence that high levels of traffic-derived air pollutants may interact with pollen and bring about more intense respiratory allergy symptoms (Hjelmroos et al., 1999; Andersen et al., 2007; Díaz et al., 2007; Alves et al., 2010). Accordingly, global warming may induce a wide pollenrelated public health problem, for which the societies should be prepared in time.

Pollen of ragweed is extremely allergenic and this is why ragweed is the most dangereous allergy-related plant and its pollen is one of the most frequent cause of hayfever. Ragweed pollen causes severe human ecological and health problems. A plant, depending on its size, may produce 100 million -3 billion pollen grains, even one million pollen grains per day (Fumanal et al., 2007). One hectare ragweed releases 66 $\mathrm{kg}$ pollen in a mere season (Šikoparija et al., 2009).

Two major allergens of ragweed pollen are Amb a I and Amb a II. Furthermore, it comprises several smalle and middle-sized protein allergens (Amb a III, IV, V, VI, VII and cystatin), as well. Getting into the airways, mucous membrane is irritated and the eyes are inflamed for sensitive people. Amb I allergen, belonging to the pectate lyase family and being a pectinolytic enzyme, is the dominant with a 90\% IgE activity. The protein is acidic, non-glycosylated, with a mass of $38 \mathrm{kDa}$ that contains two chains of $26 \mathrm{kDa}$ and $12 \mathrm{kDa}$, respectively (Wopfner et al., 2005).

Symptoms due to common ragweed include a runny nose, sneezing, puffy or irritated eyes, and a stuffy or itchy nose and throat, as well as hay-fever allergies (Matyasovszky et al., 2011). Furthermore, A. artemisiifolia has a wide ecological tolerance and can colonize a large range of disturbed habitats (Kazinczi et al., 2008a; Pinke et al., 2011; Makra et al., 2014). Its invasion is also facilitated by its resistance to certain herbicides (Kazinczi et al., 2008b), the lack of natural enemies (MacKay and Kotanen, 2008) and the high genetic variability of invasive populations (Genton et al., 2005; Chun et al., 
2010). These harmful effects, with its potential for rapid spread has made ragweed one of the most dangerous invasive non-native species in Europe. The European Commission has identified the species as a significant problem for many Member States of the EU and a very serious threat for others.

\section{Sensitivity thresholds}

In Hungary, Kadocsa et al. (1991) detected sensitization against ragweed pollen even above 10 pollen grains / $\mathrm{m}^{3}$ of air / day. Zink et al. (2012) found that allergic reaction may occur at a pollen concentration of 12 pollen grains $/ \mathrm{m}^{3}$ of air / day. For pollen sensitive patients, threshold value of clinical symptoms is generally 20 pollen grains / $\mathrm{m}^{3}$ of air / day (Jäger, 1998). At the State Public Health Office, Hungary the threshold value is 30 pollen grains $/ \mathrm{m}^{3}$ of air / day (Mányoki et al., 2011). At the same time, Juhász (1995) suggests 50 pollen grains $/ \mathrm{m}^{3}$ of air / day at which threshold around 60$80 \%$ of patients suffering from hay fever are sensitive to ragweed pollen.

Contrarily, besides the Carpathian Basin in those regions where ragweed pollen counts are substantially smaller, even a very low pollen load (1-2 pollen grains $/ \mathrm{m}^{3}$ of air / day) may produce slight allergic symptoms (Déchamp et al., 1997). Taking this into account a so called "subpathological risk period" has been introduced, when ragweed pollen concentration is a mere 0.1 pollen grains $/ \mathrm{m}^{3}$ of air / week, under the condition that the next week a higher pollen concentration occurs. The next level is the first week, when pollen load reaches 5 pollen grains $/ \mathrm{m}^{3}$ of air / week. This is the so called "pathological risk period" (Déchamp et al., 1997).

\section{Benefits, positive effects}

\section{Feeding}

Sheep and goats feed ragweed with pleasure in every phenophase. For sheep, feeding value of the whole plant, the seeds and the seed meal were studied, respectively. It was concluded that both the whole plant and the seed meal were very well utilizable feed containing protein, they were easily digestible and were characterised by balanced amino acid composition. However, undamaged seeds get through the body of the sheep undigested (Husvéth et al., 1999).

\section{Phytoremediation}

Ragweed can be used well for phytoremediation purposes, namely for extracting heavy metal content, especially lead content of the soil, because ragweed effcetively pick up and accumulate them. It was observed that spreading of Ambrosia is much more extended over agricultural areas, since the soil comprises more nutrients. Ragweed exploits higher nutrient spots and their growing and spreading occur at a higher rate there than over nutrient-poor areas. Their above-mentioned feature can be used since heavy metals can be accumulated with a higher rate facilitating bioremediation (Kazinczi et al., 2008b).

According to Patterson (1995), at higher $\mathrm{CO}_{2}$ level ragweed produces more biomass with higher quality.

Heavy metals are strongly adsorbed in the soil and, as a result, they appear in water systems and, in this way, in groundwater and even in the drinking water network, as well. Quickly spreading plants can prevent this process. A. artemisiifolia can bind 
especially large volume of heavy metals; namely, $500 \mathrm{mg} / \mathrm{kg}$ from cobalt, $2000 \mathrm{mg} / \mathrm{kg}$ from lead and 500mg/kg from zinc. Ragweed leaf adsorbs significantly more lead and zinc than the control plant (Taylor, 2005).

Their seed is an important nutrient for birds due to its high oil content, especially in winter (Húsvéth et al., 1999).

\section{Ecological and biological control options against ragweed}

In addition to traditional procedures, biological control would also be important against ragweed. A certain bug seems to be successfully applied against Ambrosia. Ragweed was introduced also into China and they spread there fast, too. According to experiments, the bug Ophraella communa (Coleoptera: Chrysomelidae) effcetively decreased the height of the plant, the number of its branches and the surrface of its leaves, as well. Even if only one bug is allowed to a plant, the young plant is damaged substantially. For an adult plant, before blooming 12 bugs per a plant caused similarly big damage as an herbicide (Guo et al., 2011).

According to experiments in Hungary, Aphis fabae, Brachycaudus helichrysi and Myzus persicae can substantially decrease the size and mass of the plant, as well as the number of flowers. Brachycaudus helichrysi preferred better ragweed than sunflower. However, Aphis fabae preferred better sunflower. At the same time, Myzus persicae did not show any specific preference. Nevertheless, during free conditions neither of the species could decrease the size of ragweed and the number of plants effectively, as ragweed grow too fast (Basky and Magyar 2009).

\section{Social costs}

Common ragweed and its pollen cause serious losses in the economy and several fields of the everyday life.

Common ragweed and its pollen cause serious losses in the economy and several fields of the everyday life. The current costs of A. artemisiifolia in terms of human health and agriculture were estimated by Bullock et al. (2010) for 40 European countries. All the costs are given in Euros at 2011 prices. The human health impacts were estimated to affect around 4 million people with total estimated medical costs of $€ 2,136$ million per year. Furthermore, total estimated workforce productivity losses and agricultural costs due to $A$. artemisiifolia as high estimates were $€ 529$ million and $€ 3,559$ million, respectively. The estimated total costs are valued at $€ 6.224$ billion per year. Over $80 \%$ of these impacts are lost crop yields. Estimated agricultural, human health, workforce and total costs are the highest in Ukraine, Romania and Hungary with $€ 995$, $€ 770$ and $€ 605$ million, respectively (Bullock et al., 2010). At the same time, in the USA, allergic disorders represent an important group of chronic diseases with estimated costs at approximately $\$ 21$ billion per year. Among twenty-five of the most harmful invasive species of China, economic losses due to ragweed, found in most of the provinces, amount to 397.9 million USD, taking ragweed the $2^{\text {nd }}$ most harmful species in the country (Ding et al., 2004; Li et al., 2014).

Realizing the danger, those countries polluted with ragweed, have introduced antiAmbrosia campaigns under the control of the National Ministries of either Health Affairs or Agriculture. 


\section{Distribution of ragweed in Europe}

A limitation of ragweed pollen observations is that the pollen of A. artemisiifolia cannot be distinguished from other species of the Ambrosia genus. In Western Europe, the first temporary colonization of Ambrosia was reported from Brandenburg and Pfaffendorf (Germany) in 1863 (Hegi, 1906; Priszter, 1960; Hodişan and Morar, 2007). In Western Europe, four American species have established: A. artemisiifolia, A. psilostachya, A. tenuifolia and A. trifida (Járai-Komlódi and Juhász, 1993; Makra et al., 2004). However, in Europe, common ragweed (A. artemisiifolia) is predominant of all Ambrosia species (Makra et al., 2005; Bullock et al., 2010; Vinogradova et al., 2010; Páldy et al., 2006) that is supported by the population genetic data of Mátyás and Vignesh (2012).

The only two native species of ragweed in Europe can only be found in some maritime locations around the Mediterranean coastal area. The earliest described colonization of seaside Ambrosia (Ambrosia maritima) occurred in Dalmatia (Croatia) in 1842 near Dubrovnik (Croatia) and Budva (Montenegro) areas and on the neighbouring islands (de Visiani, 1842). While, in the western basin of the Mediterranean, A. maritima (Balearic Islands) and A. tenuifolia (Minorca Island) are autochton species (Fraga and García, 2004). According to some botanists they are native, while others consider them as an annual variant of $A$. psilostachya or a variant of A. artemisiifolia. A. psilostachya occurs only sporadically in Europe (Szigetvári and Benkö, 2004). However, according to the genetic analysis of both 100-year old items coming from herbaria and recently collected plants, the current population has of much higher genetic and allelic diversity than 100 years ago. Based on a study using eight microsatellite loci, among recent populations in Europe the genetic distance is smaller and the populations are less structured then ever (Chun et al., 2010). Using NimbleGen microarray, Hodgins et al. (2013) looked for genes that could contribute to the successful spreading of ragweed in Europe. They compared several European and American populations, as well as populations living in different enviroments (control, light stress and nutritional stress). They found around 180 genes that were modified in popuations settled in Europe. These genes have a role in producing secondary metabolites and stress tolerance, as well as in degradation of xenobiotics (Hodgins et al., 2013).

The distribution of A. artemisiifolia in Europe started after the First World War (Makra et al., 2014). Seeds of different Ambrosia species were transported to Europe from America by purple clover seed shipments, and grain imports. Major nodes of its distribution pathways are European ports, namely Rijeka (Croatia) towards Croatia and the western part of Hungary (Járai-Komlódi and Juhász, 1993; Makra et al., 2005), Trieste and Genoa (Italy) towards Northern Italy (Járai-Komlódi and Juhász, 1993; Makra et al., 2005), Marseille (France) towards the Rhône valley in France (JáraiKomlódi and Juhász, 1993; Comtois, 1998; Makra et al., 2005) and Odessa (Ukraine) towards southern and eastern Ukraine (Rodinkova et al., 2012). After having been settled in Europe, ragweed spread quickly, since herbivorous and granivorous species harrmful for A. artemisiifolia in its homeland were missing from Europe (Mackay and Kotanen, 2008).

The most important habitat areas of ragweed and the highest pollen concentrations occur, in decreasing order of the pollen levels, (1) in the southern, eastern and the northern-eastern parts of Ukraine (Rodinkova et al., 2012), (2) in the Pannonian Plain in Central Europe including Hungary and some parts of Serbia, Croatia, Slovenia, 
Slovakia and Romania (Makra et al., 2005; 2014), (3) in the Rhône valley in France (Déchamp and Cour, 1987, Laaidi and Laaidi, 1999; Chauvel et al., 2006; Gladieux et al., 2011), (4) in the south-western part of the European Russia (Reznik, 2009), furthermore (5) in north-western Milan and south Varese (Lombardy, Po River valley) in Italy (Carosso and Gallesio, 2000; Bonini et al., 2012). Less extended habitat areas with smaller pollen levels occur in the Balkan Peninsula (Yankova et al., 2000; Dimitrov and Tzonev, 2002; Šikoparija et al., 2009), in the remaining part of the European Russia (Reznik, 2009), Switzerland (Clot et al., 2002), Germany (Zink et al., 2012), Czech Republic (Rybníček et al., 2000), Poland (Kasprzyk et al., 2011), Bulgaria (Yankova et al., 2000), the Baltic States (Saar et al., 2000), Spain (FernandezLlamazares et al., 2012) and they even occur casually in Sweden (Dahl et al., 1999). At the same time, the northern border of its permanent occurrence is the $55^{\circ} \mathrm{N}$ latitude in Europe, namely the southern parts of Poland and Germany (Szigetvári and Benkö, 2004). Historic spread of A. artemisiifolia for the European countries is reported by Buttenschøn et al. (2009) and Bullock et al. (2010) in detail.

Bullock et al. (2010) synthesised and reviewed (1) the information on the current extent of ragweed infestation in Europe; (2) the measures controlling ragweed spread and (3) the economic, social and environmental aspects of harmful effects in all economic sectors.

\section{Ragweed in individual countries, worldwide}

Ragweed in Hungary may have originated in Canada, rather than the United States (Cseh et al., 2008). Here, A. artemisiifolia was firstly described in Budapest in 1888 (Thaisz, 1910) then in Orsova and Herkulesfürdö (Lower-Danube region, in the historical Hungary) in 1907 and 1908 (Jávorka, 1910; Csontos et al., 2010). As an arable weed, its first appearance in the South-Transdanubian part of Hungary (i.e. on the south-western part of the Pannonian Plain) was proved near Somogyvár (Somogy county) in 1922 in the south-western part of Hungary (Lengyel, 1923). Since then, they have been spread rapidly towards the north-east parts of the country. Between the Danube and Tisza rivers A. artemisiifolia was spread from Szeged city, in the middle of the Pannonian Plain, towards North-Hungary (Tímár, 1955). Recently the annual ragweed pollen level is 36-45\% of the total annual pollen release in Szeged (Juhász, 1998). East from the Danube, the northern part of Pannonian Plain was infected from Szeged city (Kazinczi et al., 2008a). By the end of the last century, Hungary was fully occupied by ragweed excluding the mountainous areas. In the 1950s, based on the Hungarian National Weed Survey, the species was ranked 21st in the weed list and has since risen to: 8th in the 1970s and to 4th by the 1980s (Járai-Komlódi, 1998; Novák et al., 2009; Bullock et al., 2010). The phases of their distribution in Hungary have been mapped by Priszter (1957; 1960) and Béres and Hunyadi (1991). Song and Prots (1998) reconstructed the invasion of Ambrosia artemisiifolia in the Pannonian Plain in Central Europe and the Ukrainian Carpathians Mountains on the basis of floristic records. They found that the spreading speed of the species was around $70 \mathrm{~km} /$ year (on the average) since the middle of the $20^{\text {th }}$ century.

The species was first recorded in Serbia around 1935 in the village of Osojci, near Derventa (Maly, 1940). The species was then recorded in 1953 around Sremski Karlovci, Petrovaradin and Novi Sad. It is believed that the species arrived from Romania on ships that sailed on the Danube (Slavnić, 1953). From the 1970s to the 
present, A. artemisiifolia has spread across a wide area of Serbia and recently it is considered to be a widespread ruderal weed species in Vojvodina often forming large, compact communities in sandy and ruderal habitats (Konstantinović et al., 2004; Bullock et al., 2010).

In Croatia, the first records of A. artemisiifolia were collected in the 1940s around Pitomaca in Central Croatia. Inland parts of the country are highly infested with $A$. artemisiifolia, while in the coastal areas it is mainly concentrated in some districts (Peternel et al., 2006; Galzina et al., 2010). A. artemisiifolia is expanding towards west, at a rate of between 6 and $20 \mathrm{~km}$ per/year (Galzina et al., 2010).

In Slovenia, A artemisiifolia was introduced at the end of the Second World War. It is now well established and spreads widely and fast in the lowlands of the country (Kofol Seliger, 1998). Spreading of A. artemisiifolia towards both Serbia (Šikoparija et al., 2009) and Bosnia and Herzegovina (Soljan and Muratović, 2004) occurred from north, i.e. from the Pannonian Plain.

Until 1995, no data were available on the distribution of Ambrosia species in Bulgaria. Yankova et al. $(1996 ; 1998)$ published the first results on Ambrosia pollen measurements in the air of Sofia, Bulgaria, that started in 1981. Here, ragweed colonization is extended in the Danubian Plain and Sofia region only (Dimitrov and Tzonev, 2002) and peak annual pollen concentrations here are very high, exceeding 10,000 pollen grains $\cdot \mathrm{m}^{-3}$ of air in several years (Yankova et al., 1996).

The source region of A. artemisiifolia in Slovakia is Csallóköz and eastern Slovakia. The first description of its presence (Komarno, Southwest Slovakia) dated back to 1949. A. artemisiifolia is partly native and partly transported either by southerly winds from Hungary or arrived via cereals transports from the former Soviet Union (Makovcová et al., 1998).

The first record for Austria is a herbarium specimen collected in 1883, while the first naturalized population was recorded in in Lower Austria, Burgenland and Linz in 1952 (Essl et al., 2009). Furthermore, fields have been colonized by the 1970s (Essl et al., 2009). Ambrosia pollen can be transported from the Pannonian Plain to eastern Austria and Vienna during August and September, when south-eastern winds are predominant in the region (Essl et al., 2009; Karrer, 2010). Jäger and Litschauer (1998) detected pollen of Ambrosia coming from western Hungary in the air of Vienna. Native Ambrosia is also found in the Austrian countryside (Jäger and Berger, 2000). The migration velocity of new plant occurrences from east to west is 6-20 km/year (Jäger and Litschauer, 1998).

In the Czech Republic, the species was first recorded in 1883 in clover fields near Třeboň and a field near Doudlevice u Plzně (Slavík and Štěpánková, 2004). Over the past 30 years A. artemisiifolia has spread from harbours, grain houses, silos, mills and transport links to lowland areas of south and north east Moravia, as well as along the Elbe valley (Slavík and Štěpánková, 2004).

Ambrosia pollen came to Switzerland by the southerly winds from Northern Italy and the Rhône valley (Peeters, 1998). However, it was recently shown that there is native Ambrosia in Geneva, Switzerland, as well (Clot et al., 2002). In the country, Ambrosia pollen was firstly observed in Basel in 1970 by Leuschner (1974).

In France, A. artemisiifolia occurred in at least three botanical gardens in the 18th century (Lyon, 1763; Paris, 1775; and Poitier, 1791) and during the first half of the 19th century in at least five gardens, namely in: Alençon, Angers, Avignon, Montpellier and Strasbourg. The earliest herbarium record in Europe also comes from France in 1863 
(Chauvel et al., 2006; Bullock et al., 2010). The species showed a gradual but continuous spread in this region, demonstrating their continuous presence in the area of Lyon, which seems to be the focus of its current French distribution (Thibaudon, 1998; Chauvel et al., 2006; Gladieux et al., 2011). The agricultural trade between America and Europe in the 19th century and the First World War facilitated the introduction and spread of A. artemisiifolia in France. The plant is spreading from north to south in the mid-Rhone valley area and it is more dominant in rural than in urban areas (Déchamp and Penel, 2002). The temporal and spatial spread of the species in France has speeded up in the last 30 years with a number of sub-regions being free of A. artemisiifolia declining dramatically from 54 in 1982; to 38 in 2004; and 9 in 2011 (Chauvel et al., 2006; Bullock et al., 2010; Petermann, 2011).

In Italy, the species was first recorded in 1901-1902 from Piedmont. A. artemisiifolia has been naturalized in the province of Milan (Lombardy) since the 1940s (Stucchi, 1942; Zanon et al., 1998); however, it has been spreading rapidly since the 1980s. Currently, the north-western Milan and south Varese (Lombardy, Po River valley) are the most polluted areas with ragweed pollen in Italy (Bonini et al., 2012).

In Spain, Ambrosia species occur only over some areas, namely northern Spain (Laínz and Loriente, 1983), the Basque Country, the Cantabric coasts and Galice (Fernández-Llamazares et al., 2012), as well as central Spain (Amor et al., 2006). The first record of the genus Ambrosia here dates back to the 19th century and corresponds to A. maritima, the only native species in the Peninsula (Pérez, 1887). The major ragweed colonies in Spain and Portugal are closely associated with some of the most important harbours, such as Barcelona, Bilbao, Lisbon, Porto, Santander or Valencia (Fernández-Llamazares et al., 2012).

In the United Kingdom, the species was first recorded as a casual species in 1836. It is considered to be increasing in range and abundance, but most records are still classed as casual (Casarini, 2002; Bullock et al., 2010).

In Germany, A. artemisiifolia was first recorded in 1860, in Hamburg. It is believed that $A$. artemisiifolia was introduced with grain and seed shipments from the USA. Up until the 1970s, A. artemisiifolia was found in only a few areas but since the 1990s it has spread eastward. The species is mostly found in the south and east of the country (Alberternst et al., 2006) in areas where anthropogenic activity is the highest (Bullock et al., 2010). Zink et al. (2012) found that in north-eastern Germany the majority of the pollen originated in local areas; however, up to $20 \%$ of the total pollen load came via long-range transport from Hungary. Furthermore, according to Boehme et al. (2009) a substantial ratio of children was sensitized by ragweed pollen in Baden Wurttemberg.

In Belgium the species was first recorded in 1883 and has since become widely spread with most records from the north of the Samber-Meuse river corridor. The majority of the records are found in the more urbanised regions (Martin and Lambinon, 2008; Bullock et al., 2010).

For Denmark, the earliest record of A. artemisiifolia dates from 1865 but today it has only a limited distribution in the country. However, the species has been noted as spreading from the established areas (Bullock et al., 2010).

In Poland, A. artemisiifolia was first introduced into Szczepanowice (Silesian Lowland - south-western Poland) in 1873. It is also possible that the species may have been introduced as early as 1613 (Tokarska-Guzik, 2005). The species has since spread to southern and central-eastern Poland (Chlopek et al., 2011). The spreading rate is poorly understood since both the species and incidence of biological recording in the 
country are increasing. However, in southern Poland A. artemisiifolia is supposed to have spread $30 \mathrm{~km}$ in the period 2007-2010 (Bullock et al., 2010; Chlopek et al., 2011). Ragweed pollen arrives in Poland from Slovakia, the Czech Republic and Austria (Kasprzyk et al., 2011). However, its most important source areas are the Pannonian Plain (Makra et al., 2010; Šikoparija et al., 2009; 2013) and the Ukraine (Rodinkova et al., 2012) not only for Poland but for all Central European countries. Their distribution here is limited to ruderal places, waste lands, lawns, sea ports, places near roads and railway tracks (Kasprzyk et al., 2011).

Concerning the Baltic area, ragweed is considered a casual species and the spreading rate is considered to be very low. A. artemisiifolia was first found in Lithuania in 1884, in Latvia in 1936 and in Estonia in 1954 (Tabaka et al., 1988; Gudžinskas, 1993; Saar et al., 2000). A. artemisiifolia is mostly recorded along railways and close to major cities (Herbarium of Institute of Biology of the University of Latvia) (Bullock et al., 2010; Šaulienè and Veriankaitè, 2012).

On the territory of Romania the species was first recorded in 1908 in Orsova (southwestern Romania), the area belonged to the Austro-Hungarian Empire at the time (Jávorka, 1910). Recently common ragweed has extended its range across the entire country with the exception of the mountainous regions (Hodişan and Morar, 2008; Bullock et al., 2010). The agricultural areas have been greatly infested. Ambrosia has extended from the west and north-west towards the central and southern part of Romania and continues to extend to the east and north-east (Ianovici and Sirbu, 2007; Skjøth et al., 2010; Ianovici et al., 2013).

In Moldova, A. artemisiifolia was first reported at Ungheni (Borza and Arvat, 1935), downstream of the Nistru River (Marza, 2010). Since its introduction, the species has spread in the south-eastern part of the country (Bullock et al., 2010; Marza, 2010).

Ambrosia was introduced to Ukraine through a few trade routes in different years. A German pharmacist Krikker grew ragweed in the Dnipropetrovsk region as a medicinal plant (substitute for quinine and as an anthelmintic remedy) in 1914 (Mar'yushkina, 1986). Ragweed was first described in the Kyiv region in 1925. The army of General Denikin brought Ambrosia with seeds of alfalfa to Eastern Ukraine, so this weed was spread in Zaporozhye, Donetsk and Lugansk regions (Rodinkova et al., 2012). The next ragweed intervention to Ukraine was registered in 1946 when the first wheat consignment was shipped to USSR from USA.

This allergenic weed is currently found in all over the country. Ragweed is usually spread from southern and eastern parts of Ukraine toward north-west by transportation, with sunflower seeds contaminated by seeds of ragweed while they are transported from steppe to forest-steppe zone of Ukraine. Sensitivity of compromised children to Ambrosia pollen in 2000 was 3\%, and in 2009 it was already $10 \%$ in the western part of Ukraine (Besh et al., 2011), which is consistent with a significant increase in Ambrosia pollen abundance (Palamarchuk et al., 2012).

In Russia, Ambrosia artemisiifolia was first recorded in the southern European part of the country in 1918 (Kovalev, 1989). The first occasional introductions were possibly connected with the increasing international trade via the Black Sea ports (Kovalev, 1989) and rail roads (Mar'yushkina, 1986). However, until the mid-sixties, there was no information on allergic properties of ragweed pollen in USSR (Ostroumov, 1964). Recently, almost $80 \%$ of the total square infested by common ragweed in Russia falls in Krasnodar territory (Moskalenko, 2002). Also Stavropol' territory, Rostov province and the Russian North Caucasus are highly infested extending southwards to Georgia. 
Furthermore, Primorsk and Khabarovsk territories (Russian Far East) are another, relatively small, isolated areas of common ragweed invasion (Reznik, 2009).

Israel is also infected with Ambrosia. The invasion of new species of Ambrosia into Israel is still in progress, mainly in the eastern Galilee and in the Sharon plain (Waisel et al., 2008).

A. artemisiifolia is extensively distributed in Asia, North and South America and Australia (Lawalrée, 1953; Priszter, 1960). The dynamic spread of A. artemisiifolia in Turkey is a serious environmental issue (Kaplan et al., 2003; Zemmer et al., 2012). Ambrosia species extensively occur in large areas of India (Singh et al., 2004; Saha and Mishra, 2009), while Ballard et al. (1995) reported that A. artemisiifolia and A. trifida are important weeds of soybean plantations here. Ragweed invaded South Korea from Europe and North America (Kil et al., 2004), while Japan from North America (Fukano and Yahara, 2012). In Japan, pollen allergy due to $A$. artemisiifolia is the $2^{\text {nd }}$ most important following Cryptomeria (Kazinczi and Novák, 2012). Populations growing in Japan produce less secondary metabolites than local plants but grow faster (Fukano and Yahara, 2012). In China, common ragweed was first documented in 1935 both in the north-eastern part of the country (Chen et al., 2007a; 2007b) and in Eastern China (Hangzhou, Jiangsu Province). Since that time on, ragweed has rapidly spread to northern, central and eastern China including over 15 provinces. Giant ragweed reportedly invaded Northeast China in the 1950s. By 1989, ragweed had expanded from centres in Shenyang, Nanjing, Nanchang and Wuhan to include 12 provinces (Wan et al., 1993; Li, 1997; Xie et al., 2001). Ragweed reated papers were published concerning the Jiangsu area (Zhan et al., 1993), the Shanghai area (Duan and Chen, 2000) and the Liaoning area (EPPO, 2013). The suitable areas for ragweed include almost exclusively the eastern, most populated part of the country with the Sichuan basin, supplemented with parts of Xinjiang Uygur Autonomous Region. This suggests that ragweed may be able to invade these areas in the future (Chen et al., 2007b). A. artemisiifolia is in abundance in the reaches of the Changjiang (Yangtze) River and along roadsides, while A. trifida along village paths and riverbanks in northeastern China (Wang et al., 1985). The species continue their southward spread into the subtropical regions of the country (Qin et al., 2012). The reason of the large-scale invasion of A. artemisiifolia in China is its great germination success over the highly variable climatic conditions (Sang et al., 2011). Li et al. (2012) found that high levels of genetic variation in China indicate that there has been no erosion of genetic variance due to a bottleneck during the introduction process. They also suggest that the successful invasion of $A$. artemisiifolia into Asia was facilitated by repeated introductions from multiple source populations in the native range creating a diverse gene pool within Chinese populations.

In the United States, the suitable region for ragweed involves almost exactly the eastern half of the country, including the Pacific coastal areas (Chen et al., 2007b). Here, in the home of Ambrosia spp., duration of the ragweed pollen season has been increasing in recent decades as a function of latitude, in association with an enhanced warming (Ziska et al., 2011). In southern Québec (Canada), A. artemisiifolia has been present since at least 200 years but the species was probably restricted to the Montréal area during the 19th century (Lavoie et al., 2007). It is unclear whether common ragweed is native here or has been introduced from the Canadian Prairies (Rousseau, 1974; Bassett and Crompton, 1975). However, this species is clearly more widespread here today than at the beginning of the 20th century (Rousseau, 1974). 
In South America, Ambrosia species are widely prevalent weeds (Sulsen et al., 2011; Masciadri et al., 2013).

In Australia, ragweed pollen is in the air in abundance for a sufficient length of time and its concentration to sensitize and provoke fall hay fever and asthma exacerbations (Bass et al., 2000).

\section{Perspectives}

At high $\mathrm{CO}_{2}$ levels, A. artemisiifolia showed substantially greater biomass, as well as increased pollen production compared to those in ambient $\mathrm{CO}_{2}$. Hence, ragweed pollen production can be expected to increase significantly under predicted future climate conditions (Wayne et al., 2002; Rogers et al., 2006).

Warming trends in long-term climate change involve greater exposure times to seasonal allergens that lead to higher risk potential of public health incidences (D'Amato and Cecchi, 2008; Shea et al., 2008).

In North America, duration of the ragweed pollen season has been increasing in recent decades as a function of latitude (Ziska et al., 2011). For Europe, future spread of ragweed will depend on the climate and land use change. Based on different models, ragweed will spread north (e.g. Germany, Poland, northern part of the European Russia) with a warmer climate compared to its current range, bringing severe impacts to areas that have yet been suffering slightly (Bullock et al., 2010; Cunze et al., 2013).

Nevertheless, there is some evidence to suppose that very high temperatures are harmful for ragweed. The highest increase in the mean temperature, especially in summer time (August), represents a limit for pollen production of Ambrosia. In this period, the loss of water makes a difficulty for phyto-physiological processes, so in order to save water the plant reduces its pollen production. This effect will limit the climate change related expansion of ragweed (Makra et al., 2011).

Concerning future economic expenses of A. artemisiifolia for Europe, without controls the influence of climate change will increase the medical and work productivity costs, but the agricultural costs will reduce. This suggests that, due to the climate change, agricultural areas will reduce and pollen sensitivity will increase in the population (Bullock et al., 2010).

Acknowledgements. Our research was supported by "Research Centre of Excellence- 85265/2014/TUDPOL.

\section{REFERENCES}

[1] Alberternst, B., Nawrath, S., Klingenstein, F. (2006): Biologie, Verbreitung und Einschleppungswege von Ambrosia artemisiifolia in Deutschland und Bewertung aus Naturschutzsicht. - Nachrichtenblatt des Deutschen Pflanzenschutzdienstes 58(11): S. 279-285.

[2] Amor Morales, Á., Navarro Andrés, F., Sánchez Anta, M.A., Valle Gutiérrez, C.J. (2006): Ambrosia artemisiifolia L. en la provincia mediterránea occidental. - Studia Botanica 25: 133-136. (in Spanish)

[3] Andersen, Z.J., Wahlin, P., Raaschou-Nielsen, O., Scheike, T., Loft, S. (2007): Ambient particle source apportionment and daily hospital admissions among children and the 
elderly in Copenhagen. - Journal of Exposure Science and Environmental Epidemiology 17(7): 625-636.

[4] Ballard, T.O., Foley, M.E., Bauman, T.T. (1995): Absorption, translocation metabolism of imazetaphyr in common ragweed (Ambrosia artemisiifolia) and giant ragweed (Ambrosia trifida). - Weed Science 43(4): 572-577.

[5] Basky, Z., Magyar, Z. (2009): Impact of indigenous aphids on development of the invasive common ragweed (Ambrosia artemisiifolia L.) in Hungary. - Journal of Pest Science 82(1): 19-25.

[6] Bass, D.J., Delpech, V., Beard, J., Bass, P., Walls, R.S. (2000): Late summer and fall (March-May) pollen allergy and respiratory disease in Northern New South Wales, Australia. - Annals of Allergy Asthma \& Immunology 85(5): 374-381.

[7] Bassett, I.J., Crompton, C.W. (1975): Biology of Canadian weeds. 11. Ambrosia artemisiifolia L. and A. psilostachya Dc. - Canadian Journal of Plant Science 55(2): 463476.

[8] Béres, I. (2003): Az ürömlevelü parlagfü (Ambrosia artemisiifolia L.) elterjedése, jelentősége és biológiája. [Distribution, importance and biology of common ragweed (Ambrosia artemisiifolia L.)]. - Növényvédelem 39(7): 293-302. (in Hungarian)

[9] Béres, I., Hunyadi, K. (1991): Az Ambrosia elatior elterjedése Magyarországon. (Distribution of Ambrosia elatior in Hungary.) - Növényvédelem 27(9): 405-410. (in Hungarian)

[10] Béres, I., Kazinczi, G., Narwal, S.S. (2002): Allelopathic Plants. 4. Common ragweed (Ambrosia elatior L. syn A. artemisiifolia), Allelopathy Journal 9(1): 27-34.

[11] Béres, I., Novák, R., Hoffmanné Pathy, Zs., Kazinczi, G. (2005): Az ürömlevelü parlagfü (Ambrosia artemisiifolia L.) elterjedése, morfológiája, biológiája, jelentősége és a védekezés lehetőségei. [Distribution, morphology, biology and importance of common ragweed (Ambrosia artemisiifolia L.) and protection facilities.] - Gyomnövények, Gyomirtás 6(1): 1-48. (in Hungarian)

[12] Besh, L.V., Vorobets, N.M., Novykevich, S.Z., Kalynovich, N.O., Svidrak, K. (2011): Osoblyvosti sezonnoi' alergii' u ditej zahidnogo regionu Ukrai'ny z pogljadu aerobiologa i klinicysta. (Features of seasonal allergy in children of western Ukraine from the point of view of an airobiologist and clinician.) - Problemy klinichnoi' pediatrii' (Problems of Clinical Pediatry) 3: 42-46. (in Ukrainian)

[13] Boehme, M.W.J., Gabrio, T., Dierkesmann, R., Felder-Kennel, A., Flicker-Klein, A., Joggerst, B., Kersting, G., Konig, M., Link, B., Maisner, V., Wetzig, J., Weidner, U., Behrendt, H. (2009): Sensitization to airborne ragweed pollen - A cause of allergic respiratory diseases in Germany? - Deutsche Medizinische Wochenschrift 134(28-29): 1457-1463.

[14] Bohár, Gy. (1996): Possibilities of biological control against common ragweed (Ambrosia artemisiifolia) with phytopathogen fungi. (A parlagfü (Ambrosia artemisiifolia L. var. elatior L. Descourt.) elleni biológiai védekezés lehetőségei kórokozó gombák segítségével). - Növényvédelem 32: 489-492. (in Hungarian)

[15] Bonini, M., Albertini, R., Brighetti, M.A., Ugolotti, M., Travaglini, A. (RIMA-Italian Monitoring Network in Aerobiology) (2012): Ragweed pollen spreading in Italy. Second International Ragweed Conference, Lyon (France), March 28-29, 2012. http://www.internationalragweedsociety.org/2ndIRC/2ndIRC2012.html. Accessed 23 October 2013

[16] Borza, A.L., Arvat, N. (1935): Iva xanthiifolia Nutt., o nouă plantă adventivă a României. - Buletinul de Informatii al Gradinii Botanice si al Muzeului Botanic dela Universitatea din Cluj 15(1-4): 186-187. (in Romanian)

[17] Bullock, J.M., Chapman, D., Schafer, S., Roy, D., Girardello, M., Haynes, T., Beal, S., Wheeler, B., Dickie, I., Phang, Z., Tinch, R., Čivić, K., Delbaere, B., Jones-Walters, L., Hilbert, A., Schrauwen, A., Prank, M., Sofiev, M., Niemelä, S., Räisänen, P., Lees, B., 
Skinner, M., Finch, S., Brough, C. (2010): Assessing and controlling the spread and the effects of common ragweed in Europe. Final report: ENV.B2/ETU/2010/0037, Natural Environment Research Council, UK, 456 p. https://circabc.europa.eu/sd/d/d1ad57e8327c.../Final_Final_Report.pdf. Accessed 19 October 2013

[18] Buttenschøn, R.M., Waldispühl, S., Bohren, C. (2009): Guidelines for management of common ragweed, Ambrosia artemisiifolia. EUPHRESCO project AMBROSIA 2008-09. 47 p. http://www.EUPHRESCO.org. Accessed 2 November 2013

[19] Carosso, A., Gallesio, M.T. (2000): Allergy to ragweed: clinical relevance in Turin. Aerobiologia 16(1): 155-158.

[20] Casarini, P. (2002): Aspetti ambientali della diffusione di Ambrosia artemisiifolia L., una pianta erbacea allergenica. - Biologia Ambientale 16(1): 49-51. (in Italian)

[21] Chauvel, B., Dessaint, F., Cardinal-Legrand, C., Bretagnolle, F. (2006): The historical spread of Ambrosia artemisiifolia L. in France from herbarium records. - Journal of Biogeography 33(4): 665-673.

[22] Chen, H., Chen, L., Albright, T.P. (2007a): Developing habitat-suitability maps of invasive ragweed (Ambrosia artemisiifolia L.) in China using GIS and statistical methods. - In: International Conference in GIS and Health; GIS for health and the environment: development in the Asia-Pacific region, Springer, Berlin, pp. 105-121.

[23] Chen, H., Chen, L.J., Albright, T.P. (2007b): Predicting the potential distribution of invasive exotic species using GIS and information-theoretic approaches: A case of ragweed (Ambrosia artemisiifolia L.) distribution in China. - Chinese Science Bulletin 52(9): 1223-1230.

[24] Chłopek, K., Dąbrowska-Zapart, K., Tokarska-Guzik, B. (2011): An assessment of the Ambrosia L. pollen threat at a regional scale using the example of the town of Sosnowiec (Silesian Uplands, Poland). - Acta Agrobotanica 64(2): 51-62.

[25] Chun, Y.J., Fumanal, B., Laitung, B., Bretagnolle, F. (2010): Gene flow and population admixture as the primary post-invasion processes in common ragweed (Ambrosia artemisiifolia) populations in France. - New Phytologist 185(4): 1100-1107.

[26] Clot, B. (2008): Recent changes in airborne pollen and allergy risk. - Environnement Risques \& Sante 7(6): 431-434.

[27] Clot, B., Gehrig, R., Peeters, A., Schneiter, D., Tercier, P., Thibaudon, M. (2002): Ambrosia pollen in Switzerland: Local production or transport? - European Annals of Allergy \& Clinical Immunology 34(4): 126-128.

[28] Comtois, P. (1998): Ragweed (Ambrosia sp.): the Phoenix of allergophytes. - In: Spieksma FThM. (ed) Ragweed in Europe. Satellite Symposium Proceedings of $6^{\text {th }}$ International Congress on Aerobiology, Perugia, Italy. p. 3-5. Alk-Abelló A/S, Horsholm, Denmark

[29] Cunze, S., Leiblein, M.C., Tackenberg, O. (2013): Range Expansion of Ambrosia artemisiifolia in Europe Is Promoted by Climate Change. - ISRN Ecology vol. 2013.

[30] Cseh, A., Taller, J. (2008): Genetic diversity of ragweed (Ambrosia artemisiifolia L.) a comparison of maternally inherited cpDNA and mtDNA. - Journal of Plant Diseases and Protection 21 (Special Issue): 389-394.

[31] Csontos, P., Vitalos, M., Barina, Z., Kiss, L. (2010): Early distribution and spread of Ambrosia artemisiifolia in Central and Eastern Europe. - Botanica Helvetica 120(1): 7578.

[32] Cunze, S., Leiblein, M.C., Tackenberg, O. (2013): Range Expansion of Ambrosia artemisiifolia in Europe is Promoted by Climate Change. - Ecology Article ID 610126, http://dx.doi.org/10.1155/2013/610126

[33] Dahl, A., Strandhede, S.O., Wihl, J.A. (1999): Ragweed: an allergy risk in Sweden? Aerobiologia 15(4): 293-297. 
[34] D'Amato, G. (2011): Effects of climatic changes and urban air pollution on the rising trends of respiratory allergy and asthma. - Multidsciplinary Respiratory Medicine 6(1): 28-37.

[35] D'Amato, G., Cecchi, L. (2008): Effects of climate change on environmental factors in respiratory allergic diseases. - Clinical and Experimental Allergy 38(8): 1264-1274.

[36] de Visiani, R. (1842): Flora Dalmatica. Vol. II. 252 p.

[37] Déchamp, C., Cour, P. (1987): Pollen counts of ragweed and mugwort (Cour collector) in 1984 measured at 12 meteorological centers in the Rhone basin and surrounding regions. - Experientia 51: 119-124.

[38] Déchamp, C., Rimet, M.L., Méon, H., Deviller, P. (1997): Parameters of ragweed pollination in the Lyon's area (France) from 14 years of pollen counts. Aerobiologia 13(4): 275-279.

[39] Déchamp, C., Penel, V. (2002). Results of pollen counts for 2001 from the Rhone-Alpes ragweed pollen-monitoring network (SARA). - Revue Francaise D'Allergologie et D'Immunologie Clinique 42: 539-542. Article No. PII S0335-7457(02)00179-X

[40] Díaz, J., Linares, C., Tobías, A. (2007). Short-term effects of pollen species on hospital admissions in the city of Madrid in terms of specific causes and age. - Aerobiologia 23(4): 231-238.

[41] Dimitrov, D., Tzonev, R. (2002): On the distribution of Ambrosia artemisiifolia L. (Asteraceae) in Bulgaria. - Phytologia Balcanica 8(1): 31-33.

[42] Ding, H., Li, M.Y., Xu, H.G. (2014): Assessing economic costs of invasive exotic species in China. In: Xu, H.G., Wang, J.M., Qiang, S. and Wang, C.Y. (eds.) Alien Species Invasion, Biosafety and Genetic Resources. Science Press, Beijing, pp. 78-128.

[43] Duan, H.P., Chen, B.L. (2000): Biological characters, encroaching habit and control strategy of common ragweed in Shanghai area. Acta Agriculturae Shanghai 16(3): 73-77.

[44] EPPO (2013): PQR database. Paris, France: European and Mediterranean Plant Protection Organization. http://www.eppo.int/DATABASES/pqr/pqr.htm

[45] Essl, F., Dullinger, S., Kleinbauer, I. (2009): Changes in the spatio-temporal patterns and habitat preferences of Ambrosia artemisiifolia during its invasion of Austria. - Preslia 81(2): 119-133.

[46] Fernández-Llamazares, A., Belmonte, J., Alarcón, M., López-Pacheco, M. (2012): Ambrosia L. in Catalonia (NE Spain): expansion and aerobiology of a new bioinvader. Aerobiologia 28(4): 435-451.

[47] Fraga, P., García, O. (2004): Notes i contribucions al coneixement de la flora de Menorca (IV). - Bolletí de la Societat d'Història Natural de Les Balears 47: 143-152. (in Spanish)

[48] Frank, F.M., Sülsen, V.P., Cazorla, S.I., Anesini, C., Muschietti, L.V., Martino, V.S. (2011): South American Medicinal Flora: A Promising Source of Novel Compounds with Antiprotozoal Activity. - Latin American Journal of Pharmacy 30(1): 202-208.

[49] Fukano, Y., Yahara, T (2012): Changes in Defense of an Alien Plant Ambrosia artemisiifolia before and after the Invasion of a Native Specialist Enemy Ophraella communa. - PLOS One 7(11): Article No. e49114 doi:10.1371/journal.pone.0049114

[50] Fumanal, B., Chauvel, B., Bretagnolle, F. (2007): Estimation of pollen and seed production of common ragweed in France. - Annals of Agricultural and Environmental Medicine 14(2): 233-236.

[51] Galzina, N., Barić, K., Šćepanović, M., Goršić, M., Ostojić, Z. (2010): Distribution of Invasive Weed Ambrosia artemisiifolia L. in Croatia. - Agriculturae Conspectus Scientificus 75(2): 75-81.

[52] Gard, B., Bretagnolle, F., Dessaint, F., Laitung, B. (2013): Invasive and native populations of common ragweed exhibit strong tolerance to foliar damage. - Basic and Applied Ecology 14(1): 28-35.

[53] Gaudeul, M., Giraud, T., Kiss, L., Shykoff, J.A. (2011): Nuclear and Chloroplast Microsatellites Show Multiple Introductions in the Worldwide Invasion History of 
Common Ragweed, Ambrosia artemisiifolia. - PLOS One 6(3): e17658 doi:10.1371/journal.pone.0017658

[54] Genton, B.J., Shykoff, J.A., Giraud, T. (2005): High genetic diversity in French invasive populations of common ragweed, Ambrosia artemisiifolia, as a result of multiple sources of introduction. - Molecular Ecology Notes 14(14): 4275-4285.

[55] Gladieux, P., Giraud, T., Kiss, L., Genton B.J., Jonot, O., Shykoff, J.A. (2011): Distinct invasion sources of common ragweed (Ambrosia artemisiifolia) in Eastern and Western Europe. - Biological Invasions 13(4): 933-944.

[56] Gudžinskas, Z. (1993): Genus Ambrosia L. (Asteraceae) in Lithuania. - Thaiszia 3(1), 89-96.

[57] Guo, J.Y., Zhou, Z.S., Zheng, X.W., Chen, H.S., Wan, F.H., Luo, Y.H. (2011): Control efficiency of leaf beetle, Ophraella communa, on the invasive common ragweed, Ambrosia artemisiifolia, at different growing stages. - Biocontrol Science and Technology 21(9): 1049-1063.

[58] Hegi, G. (1906): Illustrierte Flora van Mittel-Europa. 6. - J.F. Lehmanns Verlag, München, pp. 496-498.

[59] Hjelmroos, M., Burkhead, T., Egen, N.B., Spangfort, M., Schumacher, M.J. (1999): Effects of automobile pollution and sunlight on variation of Bet v I content of birch pollen. Journal of Allergy and Clinical Immunology 103: S91-S91, Part 2, Meeting Abstract: 347.

[60] Hodgins, K.A., Lai, Z., Nurkowski, K., Huang, J., Rieseberg, L.H. (2013): The molecular basis of invasiveness: differences in gene expression of native and introduced common ragweed (Ambrosia artemisiifolia) in stressful and benign environments. - Molecular Ecology 22(9): 2496-2510.

[61] Hodgins, K.A., Rieseberg, L. (2011): Genetic differentiation in life-history traits of introduced and native common ragweed (Ambrosia artemisiifolia) populations. - Journal of Evolutionary Biology 24(12): 2731-2749.

[62] Hodişan, N., Morar, G. (2008): Spreading of the Invasive Species Ambrosia artemistifolia L. a Quarantine Weed in Southern and South-Eastern Romania. - Proceedings, $43^{\text {rd }}$ Croatian and $3^{\text {rd }}$ International Symposium on Agriculture pp. 711-714.

[63] Husvéth, F., Szegleti C, Béres I, Munkás I, Magyar L, Szöllőskei G, 1999. In vivo and in vitro reticuloruminal studies of Ambrosia artemisiifolia (A. elatior). In: Future Prospects for Hungarian Animal Production (Challenges and Opportunities). Scientific Conference at the Hungarian Academy of Sciences, 24 November 1999. Állattenyésztes és Takarmányozás, 48(6):707-710.

[64] Ianovici, N., Panaitescu, C.B., Brudiu, I. (2013): Analysis of airborne allergenic pollen spectrum for 2009 in Timişoara, Romania. - Aerobiologia 29(1): 95-111.

[65] Ianovici, N., Sirbu, C. (2007): Analysis of airborne ragweed (Ambrosia artemisiifolia L.) pollen in Timişoara, 2004. - Analele Universitãţii din Oradea Fascicula Biologie 14: 101108.

[66] Jäger, S. (1998): Global aspects of ragweed in Europe. - In: Spieksma, F.Th.M. (ed.) Ragweed in Europe. 6th International Congress of Aerobiology, Perugia, Italy 1998. Satellite Symposium Proceedings pp. 6-10. Alk-Abelló A/S, Horsholm DK

[67] Jäger, S., Berger, U. (2000): Trends in Ambrosia pollen counts vs. RAST positivity in a Viennese population for the years 1984-1999. - In: Jäger, S. (ed.) 2nd European Sympsium on Aerobiology, Vienna 2000. Abstract Vol. M808. Vienna; http://betula.hno.akh-wien.ac.at/s2000/abstracts/html. Accessed 29 October 2013

[68] Jäger, S., Litschauer, R. (1998): Ragweed (Ambrosia) in Austria. - In: Spieksma, F.Th.M. (ed.) Ragweed in Europe. 6th International Congress of Aerobiology, Perugia, Italy 1998. Satellite Symposium Proceedings pp. 22-26. Alk-Abelló A/S, Horsholm, Denmark 
[69] Járai-Komlódi, M. (1998): Ragweed in Hungary. - In: Spieksma, F.Th.M. (ed.) Ragweed in Europe. $6^{\text {th }}$ International Congress of Aerobiology, Perugia, Italy 1998. Satellite Symposium Proceedings pp. 33-38. Alk-Abelló A/S, Horsholm DK

[70] Járai-Komlódi, M., Juhász, M. (1993): Ambrosia elatior (L.) in Hungary (1989-1990). Aerobiology 9(1): 75-78.

[71] Jávorka, S. (1910): Ambrosia artemisiifolia (L.) in Hungary. - Botanikai Közlemények 9: 303-333.

[72] Juhász, M. (1995): A délmagyarországi aeropalinológiai kutatások új eredményei. (New results of aeropalynological research in Southern Hungary.) - A Magyar Tudományos Akadémiai Szegedi Akadémiai Bizottságánalk Kiadványai. (Publications of the Regional Committee of the Hungarian Academy of Sciences.) Szeged, 5: 17-30. (in Hungarian)

[73] Juhász, M. (1998): History of ragweed in Europe. - In: Spieksma, F.Th.M. (ed.) Ragweed in Europe. $6^{\text {th }}$ International Congress of Aerobiology, Perugia, Italy 1998. Satellite Symposium Proceedings pp. 11-14. Alk-Abelló A/S, Horsholm DK

[74] Kadocsa, E., Bittera, L., Juhász, M. (1991): Pollenszámlálás alapján végzett bőrtesztek eredményei nyárvégi szezonalitású rhinitis allergicás betegeken. (Results of skin prick tests based on pollen counts for patients suffering from late summer seasonal allergic rhinitis.) - Orvosi Hetilap 32(29): 1589-1591. (in Hungarian)

[75] Kaplan, A., Sakiyan, N., Pinar, N.M. (2003): Daily Ambrosia pollen concentration in the air of Ankara, Turkey (1990-1999). - Acta Botanica Sinica, 45(12): 1408-1412.

[76] Karrer, G. (2010): 2. Zwischenbericht zum Projekt "Ausbreitungsbiologie und Management einer eingeführten und extrem allergenen Pflanze, Wege und Ursachen der Ausbreitung von Ragweed (Ambrosia artemisiifolia)" (2nd interim report on the project „spread Biology and Managment of an established and highly allergic plant, roads and causes of the spread of ragweed (Ambrosia artemisiifolia). BBK-Projekt Nr. 100198_4, 14.12.2009, $80 \mathrm{p}$.

[77] Kasprzyk, I., Myszkowska, D., Grewling, L., Stach, A., Šikoparija, B., Skjøth, C.A., Smith, M. (2011): The occurrence of Ambrosia pollen in Rzeszów, Kraków and Poznań, Poland: investigation of trends and possible transport of Ambrosia pollen from Ukraine. International Journal of Biometeorology 55(4): 633-644.

[78] Kazinczi, G., Béres, I., Novák, R, Bíró, K, Pathy, Zs. (2008a): Common ragweed (Ambrosia artemisiifolia): A review with special regards to the results in Hungary. I. Taxonomy, origin and distribution, morphology, life cycle and reproduction strategy. Herbologia 9(1): 55-91.

[79] Kazinczi, G., Béres, I., Pathy,, Z., Novák, R. (2008b): Common ragweed (Ambrosia artemisiifolia L.): a review with special regards to the results in Hungary: II. Importance and harmful effect, allergy, habitat, allelopathy and beneficial characteristics. Herbologia 9(1): 93-118.

[80] Kazinczi, G., Novák, R. (eds.) (2012): A parlagfü visszaszorításának integrált módszerei. (Integrated methods of rolling back of ragweed.) Gyommentes Környezetért Alapítvány (Fund for weed-free environment), Budapest, 225 p, ISBN: 978-963-08-4036-1 (in Hungarian)

[81] Kil, J.H. Shim, K.C., Park, S.H., Koh, K.S., Suh, M.H., Ku, Y.B., Suh, S.U., Oh, H.K., Kong, H.Y. (2004). Distributions of naturalized alien plants in South Korea. - Weed Technology 18, Supplement 1, 1493-1495.

[82] Kiss, L., Béres, I. (2006): Anthropogenic factors behind the recent population expansion of common ragweed (Ambrosia artemisiifolia) in Eastern Europe: is there a correlation with politial transitions? - Journal of Biogeography 33(12): 2156-2157.

[83] Kofol Seliger, A. (1998): Ragweed in Slovenia. - In: Spieksma, F.Th.M. (ed.) Ragweed in Europe. $6^{\text {th }}$ International Congress of Aerobiology, Perugia, Italy 1998. Satellite Symposium Proceedings pp. 39-41. Alk-Abelló A/S, Horsholm, Denmark 
[84] Konstantinović, B., Meseldžija, M., Konstantinović, B. (2004): Ambrosia artemisiifolia L. Spreading in urban environment and possibilities of control. - Acta Herbologica 13(2): 449-452.

[85] Kovalev, O.V. (1989): Spread out of adventive plants of Ambrosieae tribe in Eurasia and methods of bilogical control of Ambrosia L. (Asteraceae). - In: (Eds: Kovalev, O.V., Belokobylsky, S.A.) Theoretical Principles of Biological Control of the Common Ragweed. Proceedings of the Zoological Institute. Vol. 189, "Nauka" Publishing House, Leningrad Branch, pp. 7-23. ISBN: 5-02-025688-9 (in Russian)

[86] Laaidi, K., Laaidi, M. (1999): Airborne pollen of Ambrosia Burgundy (France) 19961997. - Aerobiologia 15(1): 65-69.

[87] Laínz, M., Loriente, E. (1983): Contribuciones al conocimiento de la flora montañesa, II. - Anales del Jardín Botánico de Madrid 39: 405-416. (in Spanish)

[88] Lavoie, C., Jodoin, Y., de Merlis, A.G. (2007): How did common ragweed (Ambrosia artemisiifolia L.) spread in Québec? A historical analysis using herbarium records. Journal of Biogeography 34(10): 1751-1761.

[89] Lawalrée, A. (1953): Note complémentaire sur les Ambrosia adventices en Europe occidentale. - Bulletin de la Société Royale de Botanique de Belgique 87: 207-208. (in French)

[90] Lengyel, G. (1923): Az Ambrosia artemisiifolia előfordulása Magyarországon. (The occurrance of Ambrosia artemisiifolia L. in Hungary.). - Botanikai Közlemények 21: 100. (In Hungarian)

[91] Leuschner, R.M. (1974): Luftpollenbestimmung in Basel während der Jahre 1969 und 1970. - Verhandlungen der Naturforschenden Gesellschaft in Basel 84(2): 521-626.

[92] Li, B., Wei, S.J., Li, H., Yang, Q., Lu, M. (2014): Invasive Species of China and their Responses to Climate Change. In (Ziska, L.H., Dukes, J.S., eds.) Invasive Species and Global Climate Change. Part II. Case Studies. Chapter 12. CAB International, Wallingford, Boston, pp. 198-216.

[93] Li, X.M. (1997): Research progress on comprehensive control of serious weed Ambrosia. - Weed Science 1: 7-10.

[94] Li, X.M., Liao, W.J., Wolfe, L.M., Zhang, D.Y. (2012): No Evolutionary Shift in the Mating System of North American Ambrosia artemisiifolia (Asteraceae) Following Its Introduction to China. - PLOS One 7(2): Article No. e31935

[95] MacKay, J., Kotanen, P.M. (2008): Local escape of an invasive plant, common ragweed (Ambrosia artemisiifolia L.), from above-ground and below-ground enemies in its native area. - Journal of Ecology 96(6): 1152-1161.

[96] Makovcová, S., Zlinká, J., Mikolás, V., Salát, D., Krio, V. (1998): Ragweed in Slovak Republic. - In: Spieksma, F.Th.M. (ed.) Ragweed in Europe. $6^{\text {th }}$ International Congress of Aerobiology, Perugia, Italy 1998. Satellite Symposium Proceedings pp. 27-28. AlkAbelló A/S, Horsholm, Denmark

[97] Makra, L., Juhász, M., Béczi, R., Borsos, E. (2005): The history and impacts of airborne Ambrosia (Asteraceae) pollen in Hungary. - Grana 44(1): 57-64.

[98] Makra, L., Juhász, M., Borsos, E., Béczi, R. (2004): Meteorological variables connected with airborne ragweed pollen in Southern Hungary. - International Journal of Biometeorology 49(1): 37-47.

[99] Makra, L., Matyasovszky, I., Deák, J.Á. (2011): Trends in the characteristics of allergenic pollen circulation in Central Europe based on the example of Szeged, Hungary. Atmospheric Environment 45(33): 6010-6018.

[100] Makra, L., Matyasovszky, I., Deák, Á.J. (2014): Ragweed in Eastern Europe. - In: (eds. Ziska L.H., Dukes, J.S.) Invasive Species and Global Climate Change. Part II. Case Studies. Chapter 8. CAB International, Wallingford, Boston, pp. 117-128.

[101] Makra, L., Sánta, T., Matyasovszky, I., Damialis, A., Karatzas, K., Bergmann, K.C., Vokou, D. (2010): Airborne pollen in three European cities: Detection of atmospheric 
circulation pathways by applying three-dimensional clustering of backward trajectories. - Journal of Geophysical Research-Atmospheres 115(D24220): doi:10.1029/2010JD014743

[102] Maly, K. (1940): Notizen zur Flora von Bosnien-Herzegovina. Glasnik Zemaljskog muzeja za Bosnu i Hervegovinu II, 1.2. Sarajevo (in German)

[103] Mányoki, G., Apatini, D., Novák, E., Magyar, D., Bobvos, J., Bobvos, G., Málnási, T., Elekes, P., Páldy A. (2011): Parlagfü - lakossági expozíció. Parlagfü helyzetkép és megoldási javaslatok az Aerobiológiai Hálózat mérései alapján és az OKI-AMO feldolgozásában. (Ragweed - exposure of the population. Report on ragweed and proposals for solutions on the basis of the measurements of the Aerobiological Network and on the processing of OKI-AMO.) Országos Környezetegészségügyi Intézet Egészséghatás Előrejelzés Főosztály, Aerobiológiai Monitorozási Osztály (National Environmental Health Institute, Health Effect Prediction Department, Aerobiological Monitoring Section), kézirat (manuscript), Budapest, 29 p. (in Hungarian) http://www.zoldholnap.hu/download/docs/Az_Orszagos_Kornyezetegeszsegugyi_Intezet _jelentese_a_parlagfu_helyzetrol.pdf

[104] Mar'yushkina, V.Ya. (1986): Common ragweed and principles of its biological control. Naukova Dumka, Kiev, USSR, 119 p. (in Russian)

[105] Martin, P., Lambinon, J. (2008): Ambrosia artemisiifolia L., l'Ambroise anuelle, en Belgique. - Natura Mosana 61, 31-46. (in French)

[106] Marza, M. (2010): Flora şi vegetația sinantropă necultivată a Republicii Moldova. PhD thesis, Universitatea de Stat din Moldova (Moldova State University), Kishinov (in Romanian)

[107] Masciadri, S., Stutz, S., García-Rodríguez, F. (2013): Modern pollen-vegetation relationship of plant communities in the Uruguayan Atlantic coast. - Brazilian Journal of Botany 36(1): 31-44.

[108] Mátyás, K.K., Vignesh, M.J.T. (2012): Population genetic analysis of common ragweed (Ambrosia artemisiifolia L.) in the Carpathian-basin. - Magyar Gyomkutatás és Technológia 13(1): 21-36.

[109] Matyasovszky, I., Makra, L., Bálint, B., Guba Z., Sümeghy, Z. (2011): Multivariate analysis of respiratory problems and their connection with meteorological parameters and the main biological and chemical air pollutants. Atmospheric Environment 45(25): 41524159.

[110] Moskalenko, G.P. (2002): Common ragweed. - Zashchita i Karantin Rastenii 2: 38-41. (in Russian)

[111] Novák, R., Dancza, I., Szentey, L., Karamán, J (2009): Arable Weeds of Hungary - Fifth National Weed Survey (2007-2008). - Ministry of Agriculture and Rural Development, Budapest, Hungary. Report, 95 p.

[112] Ostroumov, A.I. (1964): Immunological characteristics of the pollen of Ambrosia artemisiaefolia. - Bulletin of Experimental Biology and Medicine 58(6): 1449-1452.

[113] Pajević, S., Borišev, M., Orčić, D., Boža, P., Nikolić N. (2010): Photosynthetic and biochemical characteristics of invasive species (Ambrosia ertemisiifolia L., Ambrosia trifida L. and Iva xanthifolia Nutt.) depending on soil humidity and phenological phase. Russian Journal of Ecology 41(6): 498-505.

[114] Palamarchuk, O., Rodinkova, V., DuBuske, L.M. (2012): A Recent Significant Increase in Ambrosia Pollen Abundance in Central Ukraine. - Journal of Allergy and Clinical Immunology 129: Supplement: AB92.

[115] Páldy, A., Apatini, D., Collins-Horváth, Z., Erdei, E., Farkas, I., Magyar, D., Józsa, E., Replyuk, E., Berty-Hardy, T., Nador, G., 2006: Ragweed pollution in Hungary, 20002005. Epidemiology, 17(6), S286-S286. Suppl. S. 
[116] Patracchini, C., Vidotto, F., Ferrero, A. (2011): Common Ragweed (Ambrosia artemisiifolia) Growth as Affected by Plant Density and Clipping. - Weed Technology 25(2): 268-276.

[117] Patterson, D.T. (1995): Weeds in a changing climate. - Weed Science 43(4): 689-701.

[118] Patzoldt, W.L., Tranel, P.J., Alexander, A.L., Schmitzer, P.R. (2001): A common ragweed population resistant to cloransulam-methyl. - Weed Science 49(4): 485-490.

[119] Peeters, A.G. (1998): Ragweed in Switzerland. - In: Spieksma, F.Th.M. (ed.) Ragweed in Europe. $6^{\text {th }}$ International Congress of Aerobiology, Perugia, Italy 1998. Satellite Symposium Proceedings pp. 16-19. Alk-Abelló A/S, Horsholm Denmark

[120] Pérez, J.M. (1887): Florula gaditana. Pars secunda. - Anales de la Sociedad Española de Historia Natural 16: 273-372.

[121] Petermann, A. (2011): Cartographie Nationale de l'Ambroisie (Ambrosia artemisiifolia L.). Paris, Étude réalisée pour le Ministère du Travail, de l'Emploi et de la Santé - FCBN: 26 p. (in French)

[122] Peternel, R., Čulig, J, Hrga, I., Hercog, P. (2006): Airborne ragweed (Ambrosia artemisiifolia L.) pollen concentrations in Croatia, 2002-2004. - Aerobiologia 22(3): 161168.

[123] Pinke, G., Karacsony, P., Czucz, B., Botta-Dukat, Z. (2011): Environmental and land-use variables determining the abundance of Ambrosia artemisiifolia in arable fields in Hungary. - Preslia 83(2): 219-235.

[124] Prentis, P.J., Pavasovic, A. (2013): Understanding the genetic basis of invasiveness. Molecular Ecology 22(9): 2366-2368.

[125] Priszter Sz (1960): Adventív gyomnövényeink terjedése. (Distribution of Adventive Weeds in Hungary.) - Keszthelyi Mezőgazdasági Akadémia Kiadványai. Mezőgazdasági Kiadó, Budapest (in Hungarian)

[126] Priszter, Sz. (1957): Magyarország adventív növényeinek ökológiai-areál-geográfiai viszonyai. (Ecological-areal-geographical Conditions of Invasive Plants in Hungary.) $\mathrm{PhD}$ Thesis. Budapest (in Hungarian)

[127] Qin, Z., Mao, D.J., Quan, G.M., Zhang, J.E., Xie, J.F., DiTommaso, A. (2012): Physiological and morphological responses of invasive Ambrosia artemisiifolia (common ragweed) to different irradiances. - Botany 90(12): 1284-1294.

[128] Reznik, S.Y. (2009): Common ragweed (Ambrosia artemisiifolia L.) in Russia: spread, distribution, abundance, harmfulness and control measures. - Ambroisie, The first international ragweed review, 26: http://www.zin.ru/labs/expent/pdfs/Reznik_2009_Ambrosia.pdf. Accessed 19 October 2013

[129] Rodinkova, V., Palamarchuk, O., Kremenska, L. (2012): The most abundant Ambrosia pollen count is associated with the southern, eastern and the northern-eastern Ukraine. Alergologia et Immunologia 9: 181.

[130] Rogers, C.A., Wayne, P.M., Macklin, E.A., Muilenberg, M.L., Wagner, C.J., Epstein, P.R., Bazzaz, F.A. (2006): Interaction of the onset of spring and elevated atmospheric $\mathrm{CO}_{2}$ on ragweed (Ambrosia artemisiifolia L.) pollen production. - Environmental Health Perspectives 114(6): 865-869.

[131] Rousseau, C. (1974): Géographie floristique du Québec/Labrador. Distribution des principales espèces vasculaires. p. 798. - Presses de l'Université Laval, Québec (in French)

[132] Rybníček, O., Jäger, S. (2001): Ambrosia (Ragweed) in Europe. - Allergy \& Clinical Immunology 13: 60-66.

[133] Rybníček, O., Novotná, B., Rybníčkova, E., Rybníček, K. (2000): Ragweed in the Czech Republic. - Aerobiologia 16(2): 287-290. 
[134] Saar, M., Gudžinskas, Z., Ploompuu, T., Linno, E., Minkienė, Z., Motiekaitytè, V. (2000): Ragweed plants and airborne pollen in the Baltic states. - Aerobiologia 16(1): 101-106.

[135] Saha, R., Mishra V.K. (2009): Effect of Organic Residue Management on Soil HydroPhysical Characteristics and Rice Yield in Eastern Himalayan Region, India. - Journal of Sustainable Agriculture 33(2): 161-176. Article No. PII 908504954

[136] Sang, W.G., Liu, X.Y., Axmacher, J.C. (2011): Germination and emergence of Ambrosia artemisiifolia L. under changing environmental conditions in China. - Plant Species Biology 26(2): 125-133.

[137] Šaulienè, I., Veriankaitè, L. (2012): Analysis of high allergenicity airborne pollen dispersion: common ragweed study case in Lithuania. - Annals of Agricultural and Environmental Medicine 19(3): 415-419.

[138] Shea, K.M., Truckner, R.T., Weber, R.W., Peden, D.B. (2008): Climate change and allergic disease. - Journal of Allergy and Clinical Immunology 122: 443-453.

[139] Šikoparija, B., Skjøth, C.A., Alm Küblerd, K., Dahl, A., Sommer, J., Grewling, Ł., Radišić, P., Smith, M. (2013): A mechanism for long distance transport of Ambrosia pollen from the Pannonian Plain. - Agriculrural and Forest Meteorology 180: 112-117.

[140] Šikoparija, B., Smith, M., Skjøth, C.A., Radišić, P., Milkovska, S., Simić, S., Brandt, J. (2009): The Pannonian plain as a source of Ambrosia pollen in the Balkans. International Journal of Biometeorology 53(3): 263-272.

[141] Simard, M.J., Benoit, D.L. (2010): Distribution and abundance of an allergenic weed, common ragweed (Ambrosia artemisiifolia L.), in rural settings of southern Quebec, Canada. - Canadian Journal of Plant Science 90(4): 549-557.

[142] Simoncsics, P., Osváth, P., Balázs, I. (1968): Qualitative analysis of pollen composition in the air. - Rheumatologia, Balneologia, Allergologia 9: 117.

[143] Singh, S., Yadav, A., Balyan, R.S., Malik, R.K., Singh, M. (2004): Control of ragweed parthenium (Parthenium hysterophorus) and associated weeds. - Weed Technology, 18(3): 658-664.

[144] Skjøth, C.A., Smith, M., Šikoparija, B.,Stach, A., Myszkowska, D., Kasprzyk, I, Radišić, P., Stjepanović, B., Hrga, I., Apatini, D., Magyar, D., Páldy, A., Ianovici, N. (2010): A method for producing airborne pollen source inventories: An example of Ambrosia (ragweed) on the Pannonian Plain. - Agricultural and Forest Meteorology, 150(9): 12031210.

[145] Slaví, B., Štěpánková, J. (eds.) (2004): Květena České republiky 7. - Academia, Praha (in Czech)

[146] Slavnić, Ž. (1953): Prilog flori našeg Podunavlja. - Glasnik biološke sekcije. Serija II / BT. 4-6. Zagreb (in Croatian)

[147] Soljan, D., Muratović, E. (2004): Distribution of Ambrosia artemisiifolia L. species in the area of Bosnia and Herzegovina. - Herbologia 5: 1-7.

[148] Song, J.S., Prots, B. (1998): Invasion of Ambrosia artemisiifolia L. (Compositae) in the Ukrainian Carpathians Mts. and the Transcarpathian Plain (Central Europe). - Korean Journal of Biological Sciences 2(2): 209-216.

[149] Stucchi, C. (1942): L'Ambrosia elatior I. nel Milanese. - Nuovo Giornale Botanico Italiano 4: 112-114. (in Italian)

[150] Szigetvári, Cs., Benkő, Zs.R. (2004): Ürömlevelü parlagfü (Ambrosia artemisiifolia). pp. 337-370. In: Mihály, B., Botta-Dukát, Z. (eds.) Özönnövények - Biológiai Inváziók Magyarországon. (Invasive Plants - Biological Invasions in Hungary.) - A KvVM Természetvédelmi Hivatalának Tanulmánykötetei, 9. (Essays of the Environmental Office of the Ministry of Enironment and Water, 9.) TermészetBúvár Alapítvány Kiadó, Budapest, 408 p. ISBN: 9638610751 (in Hungarian)

[151] Tabaka, L., Gavrilova, G., Fatare, I. (1988): Flora of Vascular Plants of the Latvian SSR. Zinatne: Riga. (in Russian) 
[152] Taylor, A.C. (2005): Phytoremediation of lead, cobalt and zinc contaminated soils by giant ragweed (ambrosia artemisiifolia): an honors thesis (HONRS 499). http://liblink.bsu.edu/uhtbin/catkey/1340536

[153] Thaisz, L. (1910): Reports of the Botanical Department about the meeting on $14^{\text {th }}$ Dec. 1910. (A növénytani szakosztály 1910. évi dec. 14-én tartott 162-ik ülésének jegyzőkönyve). - Botanikai Közlemények 11: 303-304.

[154] Thibaudon, M. (1998): Ragweed in France. In Lyon, France, 1987-1997. - In: Spieksma, F.Th.M. (ed.) Ragweed in Europe. $6^{\text {th }}$ International Congress of Aerobiology, Perugia, Italy 1998. Satellite Symposium Proceedings p. 15. Alk-Abelló A/S, Horsholm DK

[155] Tímár, L. (1955): Egy veszedelmes gyomkártevő előőrsei Szegeden. (Outposts of a dangerous wed pest in Szeged.) - Dél-Magyarország, Szeged, 1955. január 18, 4. (in Hungarian)

[156] Tokarska-Guzik, B. (2005): The establishment and spread of alien plant species (kenophytes) in the flora of Poland. 2372. -Wydawnictwo Uniwersytetu Śląskiego, Katowice, pp. 192.

[157] Varga, P., Béres, I., Reisinger, P, (2002): The competitive effect of three dangerous weeds on the yields of maize in different years. - Növényvédelem 38(5): 219-226.

[158] Vinogradova, Y.R., Majorov, S.R., Khorun, L.V. (2010): Black Book of Central Russia: Alien Species of flora of Central Russia. (in Russian). - GEOS, Moscow

[159] Voevodin, A.V. (1982): Weeds resistant to herbicides. - Sel'skoe Khozyaistvo za Rubezhom 8: 30-34.

[160] Wagner, W.H., Beals, T.F. (1958): Perennial ragweeds (Ambrosia) in Michigan, with the description of a new intermediate taxon. - Rhodora 60: 178-204.

[161] Waisel, Y., Eshel, A., Keynan, N., Langgut, D. (2008): Ambrosia: A New Impending Disaster for the Israeli Allergic Population. - Israel Medical Association Journal 10(12): 856-857.

[162] Wan, F.H., Guan, G.Q. (1993): Ragweed and its Comprehensive Control. - Chinese Science and Technology Press, Beijing

[163] Wang, S.Y., Spongberg, S.A., Rubenstein, J.S., Rubenstein, H.S. (1985): Ragweed in China. - Nature 316: 386-386.

[164] Wayne, P., Foster, S., Connolly, J., Bazzaz, F., Epstein, P. (2002): Production of allergenic pollen by ragweed (Ambrosia artemisiifolia L.) is increased in $\mathrm{CO}_{2}$-enriched atmospheres. - Annals of Allergy Asthma \& Immunology 88(3): 279-282.

[165] Wopfner, N., Gadermaier, G., Egger, M., Asero, R., Ebner. C., Jahn-Schmid. B., Ferreira, F. (2005): The spectrum of allergens in ragweed and mugwort pollen. - International Archives of Allergy and Immunology 138(4): 337-346.

[166] Xie, Y., Li, Z.Y., Gregg, W.P., Li, D.M. (2001): Invasive species in China - an overview. - Biodiversity and Conservation, 10(8): 1317-1341.

[167] Yankova, R., Baltadjieva, D., Peneva, R., Zlatev, V. (1996): Pollen grains of Ambrosia in the air of Sofia, Bulgaria. - Aerobiologia 12(1): 273-277.

[168] Yankova, R., Zlatev, V., Baltadjieva, D., Mustakov, T., Mustakov, B. (1998): Ragweed in Bulgaria. - In: Spieksma, F.Th.M. (ed.) Ragweed in Europe. $6^{\text {th }}$ International Congress of Aerobiology, Perugia, Italy 1998. Satellite Symposium Proceedings pp. 42-45. AlkAbelló A/S, Horsholm DK

[169] Yankova, R., Zlatev, V., Baltadjieva, D., Mustakov, T., Mustakov, B. (2000): Quantitative dynamic of Ambrosia pollen grains in Bulgaria. - Aerobiologia 16(2): 299301.

[170] Zanon, P., Berra, D., Alesina, R., Cirla, A., Corsico, R., Guidoboni, A. (1998): Spread of ragweed allergy in Lombardy (North Italy). - In: Spieksma, F.Th.M. (ed.) Ragweed in Europe. $6^{\text {th }}$ International Congress of Aerobiology, Perugia, Italy 1998. Satellite Symposium Proceedings pp. 20-21. Alk-Abelló A/S, Horsholm DK 
[171] Zemmer, F., Karaca, F., Ozkaragoz, F. (2012): Ragweed pollen observed in Turkey: Detection of sources using back trajectory models. - Science of the Total Environment 430: 101-108.

[172] Zhan, W.M,. Luo Y.L., Jiang, R.C. (1993): Study on selective herbicides for control of Ambrosia artemisiifolia at different stages. Plant Protection, 19(2): 37.

[173] Zink, K., Vogel, H., Vogel, B., Magyar, D., Kottmeier, C. (2012): Modeling the dispersion of Ambrosia artemisiifolia L. pollen with the model system COSMO-ART. International Journal of Biometeorology 56(4): 669-680.

[174] Ziska, L., Knowlton K., Rogers, C., Dalan, D., Tierney, N., Elder, M.A., Filley, W., Shropshire, J., Ford, L.B., Hedberg, C., Fleetwood, P., Hovanky, K.T., Kavanaugh, T., Fulford, G. Vrtis, R.F., Patz, J.A., Portnoy, J., Coates, F., Bielory, L., Frenz, D. (2011): Recent warming by latitude associated with increased length of ragweed pollen season in central North America. - Proceedings of the National Academy of Sciences of the United States of America 108(10): 4248-4251.

[175] Ziska, L.H., Gebhard, D.E., Frenz, D.A., Faulkner, S., Singer, B.D., Straka, J.G. (2003): Cities as harbingers of climate change: Common ragweed, urbanization, and public health. - Journal of Allergy and Clinical Immunology 111(2): 290-295.

[176] Ziska, L.H., George, K., Frenz, D.A. (2006): Establishment and persistence of common ragweed (Ambrosia artemisiifolia L.) in disturbed soil as a function of an urban-rural macro-environment. - Global Change Biology 13(1): 266-274. 